\title{
複数箇所で流出・復流する洪水氾濫流に道路等が 及ぼす影響を考慮した数値解析と実験的検証 NUMERICAL AND EXPERIMENTAL EXAMINATIONS ON LATERAL EXCHANGE OF FLOOD WATER BETWEEN A FLOOD PLAIN AND RIVER CHANNEL OCCURING IN A PLURALITY OF CHANNEL
}

\author{
秋山 壽一郎 ${ }^{1} \cdot$ 重枝 未玲 ${ }^{2} \cdot$ 中上 竜吾 ${ }^{3} \cdot$ 竹下 大祐 $^{3}$ \\ Juichiro AKIYAMA, Mirei SHIGE-EDA, Ryugo NAKAUE and Daisuke TAKESHITA \\ 1フェロー会員 Ph.D. 九州工業大学大学院教授 工学研究院建設社会工学研究系 \\ ( ₹804-8550 北九州市戸畑区仙水町1-1) \\ 2正会員 博士(工学) 九州工業大学大学院准教授 工学研究院建設社会工学研究系(同上) \\ 3学生会員 九州工業大学大学院 工学府建設社会工学専攻(同上)
}

\begin{abstract}
This study is concerned with lateral exchange of flood water between the flood plain, where a banking structure exists, and river channel, due to breach flows from river channel as well as return flows of flood water. The study is directed toward the examination of lateral exchange of flood water simultaneously occurring in a plurality of river channel. It is demonstrated that a proposed numerical model, that comprises the finite volume method based on unstructured grid using flux-difference splitting (FDS) technique and numerical method to solve simultaneously flows in a channel and inundation flows in a flood plain along with appropriate boundary conditions is effective to simulate the above mentioned complex lateral exchange of flood water.
\end{abstract}

Key Words : dyke breach, overflow, open levee, dynamic flood simulation numerical model, FDS

\section{1.はじめに}

2000年9月東海豪雨災害以降に発生した主要な豪雨災 害には，降雨状況や流域特性などの理由から各水災に固 有の課題はあるものの，(1)ハード対策については，上下 流/本支川，内水/外水処理の治水バランス，(2)フト対 策については，計画の想定をはるかに上回る豪雨，短時 間集中豪雨や局地的豪雨への対応，および危機管理上の 不備といった共通する課題が見られる1)。このような課 題の背景には, 外力の変化や治水施設の整備の進捗の遅 れなどがあるものの，事前に豪雨災害がもたらす水災リ スクが把握されていないことや，流域の各種の治水施設 の治水バランスが評価されていないことなどがある.

ハード対策の課題である治水バランスについては，上 下流/本支川のように計画手法が同様な場合は通常用い られる治水安全度のバランスとしてみることができるが， 内水/外水処理のように対象降雨や計画手法が異なって いる場合はそのような見方では治水バランスの評価は難 しく, 各施設が受け持つ雨水の処理量や貯留量のバラン スとして捉える必要がある. そのような各施設の分担流
量としての捉え方は，下水道に限らず，内水排除施設や オフサイト貯留など, 対象降雨や計画手法が異なる各種 の治水施設にも当てはまる，ところが，必ずしも各施設 の分担流量が適正に評価され，また治水施設群(治水シ ステム)の治水バランスが評価されているわけではない.

ソフト対策についても，想定を上回る豪雨等が発生し た場合に予想される水災リスクを事前に把握しておかな い限り，的確な対応は不可能であるし，また実効性のあ る危機管理体制を構築することはできない，しかし現状 ではそのようなリスク把握が行われているわけではない. 被害軽減を図っていくためには，流域の治水施設群 (治水システム)の治水バランスを図るとともに，計画の 想定を超える豪雨や計画で想定されていない豪雨がもた らす水災リスクを事前に把握し，実効性のある危機管理 体制を構築していくことが，これから極めて重要になる.

筆者は，そのような考え方から，流域を対象として任 意の降雨外力と本川下流端水位のみを所与の条件とし, 都市域における道路・市街地などの都市構造, 地形起伏 などの自然的要素を高い解像度で捉え, 河川, 下水道, 洪水調節施設などの各種治水施設の雨水処理能力および その総体としての治水システムのトータルバランスを評 


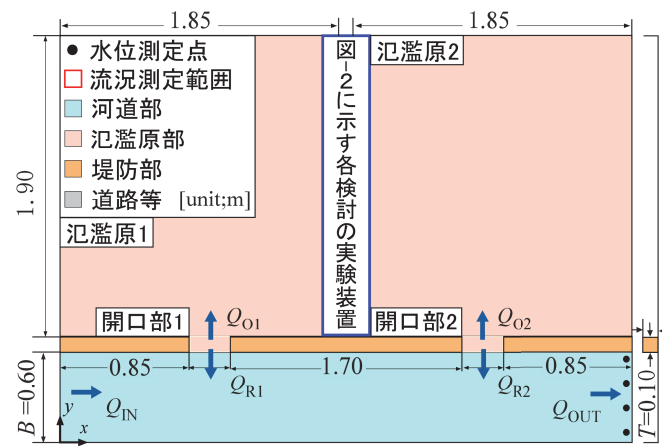

図-1＼cjkstart実験装置の概要と重要な諸量(平面図)

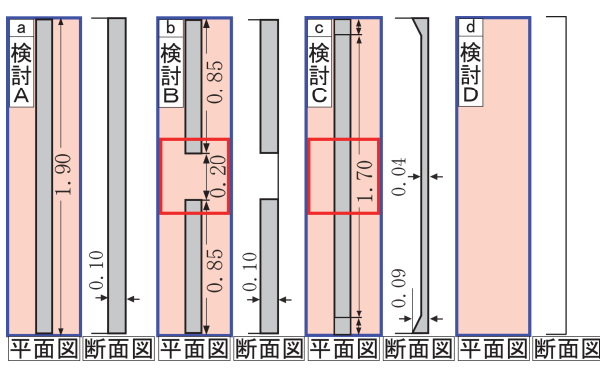

図-2 実験装置(平面図およひ断面図) (a:検討 $A, b$ : 検討 $B, c$ : 検討 $C, d$ : 検討D)

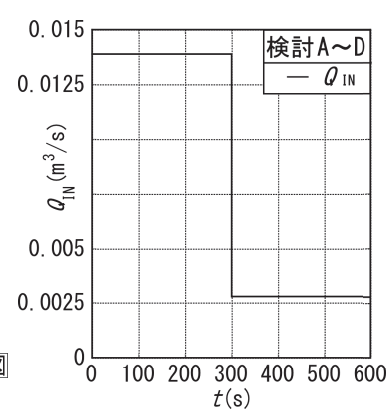

図-3 流入流量ハイドログラフ $Q_{\mathrm{IN}}$

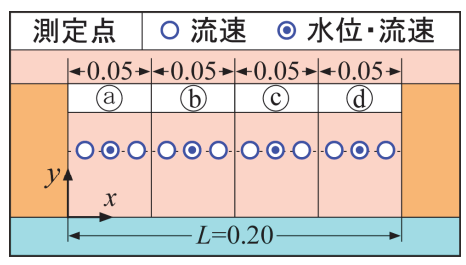

図-4 開口部の拡大図

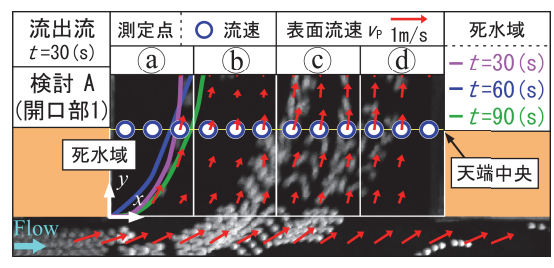

図-5 開口部の流況 (左 : 流出流，右 : 復流)
価でき，計画規模を超える豪雨や集中豪雨が発生した場 合の内・外水の水災リスクを把握できるシミュレータの 開発に取り組んでいる2),3),4),5).

そのようなシミュレータでは, 2004 年 7 月の新潟福 島豪雨災害時の信濃川水系等の水災のように, 水系各所 で同時多発的に発生する越水や破堤，河道への汇濫水の 復流といった河道と汇濫原の間での複雑な雨水のやり取 りを適正に取り扱えるだけではなく6)，汇濫原が道路等 の盛土構造物等で分断されている場合は，盛土構造物に 設けられた通路や不陸部を介して汇濫原間を流動する汇 濫水の挙動と, その影響を受けて決壊口から汇濫原一流 出する汇濫水と汇濫原から河道に復流する汇濫水の流量 を適正に把握できる必要がある.

本研究は, 以上を踏まえ, 汇濫原が道路等で分断され, かつ各決壊口から流出と復流が同時に起こる複数の浸水 パターンを取り上げ，シミュレータを構成する自由表面 流モデル2)が，そのような複雑な浸水プロセスの流出， 復流流量を河道上下流の境界条件のみから再現・予測可 能であることを模型実験に基づき実証したものである.

\section{2. 実験の概要}

「1.はじめに」で述べたような目的から，氾濫水が 河道に沿った2箇所の決壊口から同時に流出あるいは復 流する次の4ケースについて検討した.

・検討A : 汇濫原が道路等で分断され，各決壊口から流 出と復流が独立に起こる場合

・検討B : 氾濫原が道路等で分断されてはいるが，それ を横断する構造物(以下「通路」という)が設けられてお り，通路を介して各決壊口からの流出と復流が影響し合 う場合
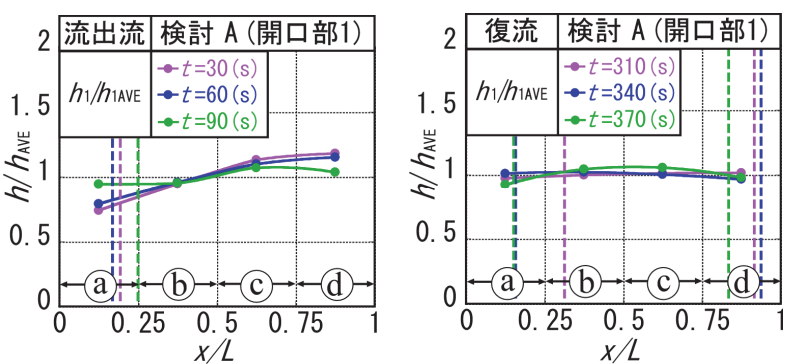

図-6 開口部の横断水位 $h$ (左 : 流出流, 右 : 復流)

・検討C : 氾濫原が道路等で分断されてはいるが，流出 水が地盤高の低くなっている道路等(以下「低地盤高区 間」という)を越流し, 各決壊口からの流出と復流が影 響し合う場合

・検討D : 氾濫原が道路等で分断されておらず，各決壊 口からの流出と復流が全体的に影響し合う場合

\section{(1) 実験装置の概要}

図-1は検討A Dで共通した実験装置の全体的な概要と 重要な諸量を, 図-2は図-1中の青枠で囲った部分の各検 討の実験装置を, 図-2中の赤枠は後述する道路等の通路 近傍の表面流速の測定範囲を示したものである.

実験装置は貯水槽部・河道部・堤防部・氾濫原部より 構成され, 河道部, 堤防敷および汇濫原部は同じ高さに 設定されている. 河道部・堤防部は, 矩形断面水路(長 $さ=3.8(\mathrm{~m})$, 幅 $B=0.6(\mathrm{~m})$, 勾配 $I=0$, 粗度係数 $n=0.01)$ の左 岸側に法面勾配 0 割の堤防(高さ $z=0.10(\mathrm{~m})$, 堤防敷幅 $T=0.10(\mathrm{~m}))$ を設置し，堤防部の一部区間に開口幅水路幅 比 $(L / B=0.33)$ の開口部を2箇所設けたものである. 河道部 の右岸側には越流しない高さの壁面が，下流端には水位 調節のための刃形堰(堰高 $s(\mathrm{~m}))$ が設けられている. その 堰高は，検討A，BおよびDではs=0.03(m)，Cでは0.05(m)

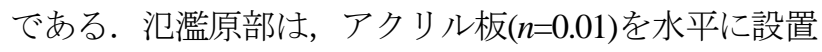


したもので，前述した検討目的に応じて異なった設定と なっている．なお以下では，開口部は上流側から開口部 1, 開口部2のように，各々に添え字 $1 ， 2$ を付けて区別し ている. 各開口部から流出あるいは復流する流量等の水 理量についても同様に区別している.

\section{（2）実験の条件と方法}

いずれの検討についても河道に両開口部から流出しな い程度の基底流量を通水させた後に，図-3に示した流入 流量ハイドログラフ $Q_{\mathbb{I N}}\left(\mathrm{m}^{3} / \mathrm{s}\right)$ を河道上流端から流入させ, 各開口部から汇濫原へ流出，復流させた。 $Q_{\mathbb{I N}}, s$ 等の実 験条件は，検討目的，実験装置の制約，測定精度を考慮 した予備実験に基づき設定した.

測定項目は，(1)流入流量ハイドログラフ $Q_{\mathbb{I N}}\left(\mathrm{m}^{3} / \mathrm{s}\right)$ ，(2) 河道下流端水位ハイドログラフ $H(\mathrm{~m})$, (3)開口部天端中 央の横断水位 $h(\mathrm{~m})$, (4)開口部での堤防法線方向の表面流 速 $v_{\mathrm{P}}(\mathrm{m} / \mathrm{s})$ および開口部，汇濫原部の通路あるいは低地盤 高区間近傍の流況である.

各諸量の測定方法は次の通りである，QIN 計を用いて測定した．Hは，図-1に示したのの地点に設 置した目盛り付の細い尺をデジタルカメラで撮影した動 画を解析し，水位の変化を読み取ることで求めた．hは， 図-4に示した青色の○の地点に目盛り付の細い尺を設置 し， $H$ と同様の測定方法で求めた。 $v_{\mathrm{p}}$ は，図-2に示した 赤枠内および図-4に示した青色の○と○の地点で直径 0.005(m)の発泡スチロール球の動きをデジタルカメラで 撮影・収録した動画をPTV解析し求めた。 また，開口部 等の流況は, PTV解析より求めた.

図-5は開口部の流況の一例を示したものである. 図中 の赤のベクトルは $=30,310(\mathrm{~s})$ の $\nu_{\mathrm{p}}$, 色付きの実線は死水 域の時間変化を示している．図-6はhを開口部天端中央 の平均水位 $h_{\mathrm{AVE}}(\mathrm{m})$ で無次元表示した一例を示したもの である．図中の丸付きの実線は $h / h_{\mathrm{AVE}}$ ，色付きの破線は 死水域幅の時間変化をそれぞれ示している.

これからわかるように，流出流，復流のいずれも死水 域の発生による偏流・縮流が生じており, hは流出流で は開口部下流側で大きくなっている一方で，復流ではそ のような傾向は認められない. このような流況を踏まえ， 開口部を（） ( に4等分し，各区間の $h$ ，水深平均流速 $V_{\mathrm{m}}(\mathrm{m} / \mathrm{s})$ より単位幅流量 $q_{\mathrm{m}}\left(=h \times V_{\mathrm{m}}\right)\left(\mathrm{m}^{2} / \mathrm{s}\right)$ を求め, これを各 区間の幅で積分して得られた流量の総和として，流出流量 $Q_{\mathrm{O}}\left(\mathrm{m}^{3} / \mathrm{s}\right)$, 復流流量 $Q_{\mathrm{R}}\left(\mathrm{m}^{3} / \mathrm{s}\right)$ ハイドログラフを算出した. 同様に, 各区間で求めた $F r\left(=V_{\mathrm{m}} /\left((g h)^{1 / 2}\right)\right.$ の平均值をもっ てFrとし， $V_{\mathrm{m}}$ は，補正係数 $\alpha(=$ 水深平均流速 $V /$ 表面流速 $\left.v_{\mathrm{P}}\right)$ を用いて $V_{\mathrm{m}}=\alpha \times v_{\mathrm{P}}$ より算出した．なお， $\alpha$ は本実験の 開口部のFroude数 $F r_{\mathrm{P}}\left(=v_{\mathrm{P}} /\left((g h)^{1 / 2}\right)\right)$ 範囲 $\left(F r_{\mathrm{P}} \fallingdotseq 0 \sim 1.6\right)$ で別 途実験を行い定めた。いずれの検討についても同一条件 下で10回の繰り返し実験を行い，度数分布から標準偏差 の範囲外の測定值を除外し，その平均值をもって実験結 果とした.

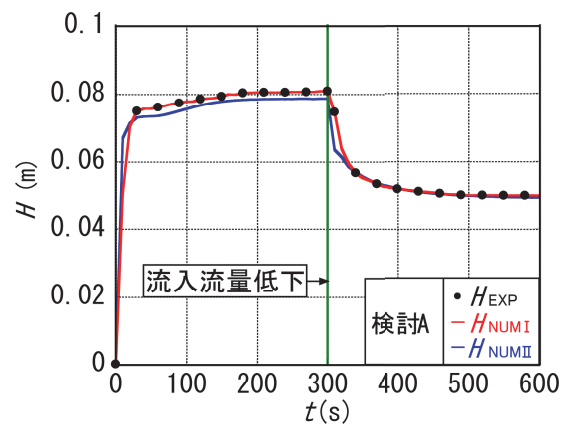

図-7＼cjkstart検討Aの下流端水位ハイドログラフH
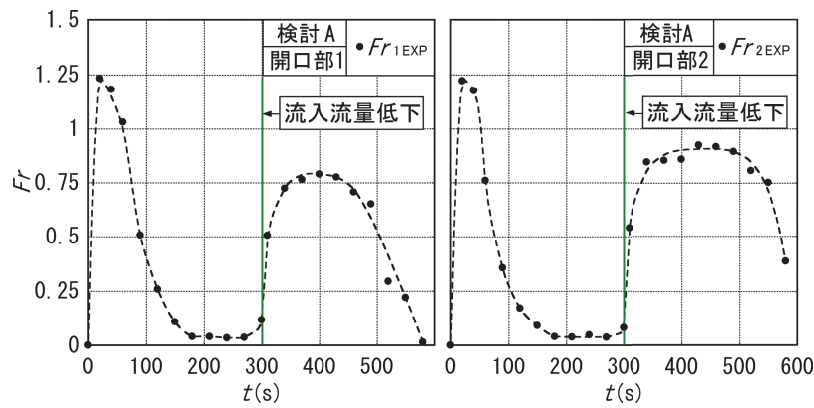

図-8 検討Aの開口部の $F r$ (左 : $F r_{1}$, 右 : $F r_{2}$ )

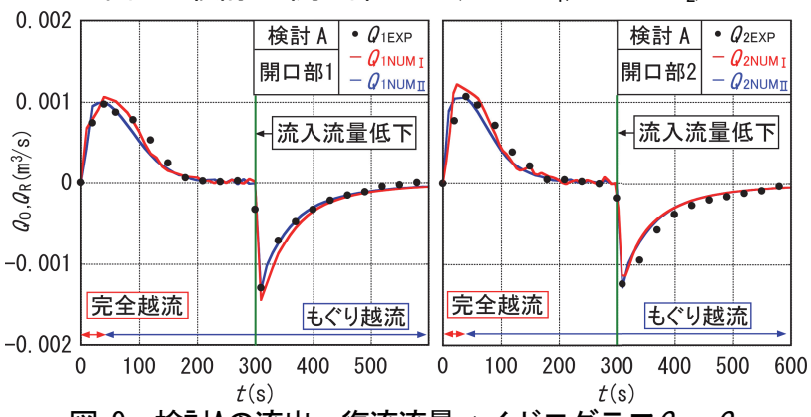

図-9 検討 $A$ の流出，復流流量ハイドログラフ $Q_{0}, Q_{R}$

(左: $Q_{1}$, 右: $\left.Q_{2}\right)$

\section{3. 解析の概要}

解析は，完全越流およびもぐり越流状態の流出，復流 を取り扱うために，常射混在流が取り扱える平面2次元 自由表面流モデルであるPSA-FUF-2DF modelによる河道

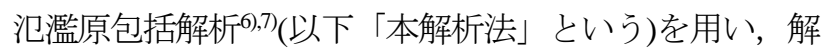
析より得られた開口部天端中央における水位 $h_{\mathrm{NUM}}(\mathrm{m})$, 堤防法線方向の水深平均流速 $V_{\mathrm{NUM}}(\mathrm{m} / \mathrm{s})$ 上り単位幅流量 $q_{\mathrm{NUM}}\left(=h_{\mathrm{NUM}} \times V_{\mathrm{NUM}}\right)\left(\mathrm{m}^{2} / \mathrm{s}\right)$ を求め, これを開口幅 $L(\mathrm{~m})$ で積 分して $Q_{\mathrm{ONUM}}\left(\mathrm{m}^{3} / \mathrm{s}\right), Q_{\mathrm{RNUM}}\left(\mathrm{m}^{3} / \mathrm{s}\right)$ を算出した.

境界条件は，河道上流端には図-3に示した流入流量八 イドログラフ $Q_{\mathbb{I N}}$ ，下流端には(1)下流端で測定した $H($ 以 下「境界条件 I」という), (2)刃形堰の公式を用いて $H-q$ 関係を算出し, 下流端の単位幅流量 $q$ から求めた $H($ 以下

「境界条件 II」という)の2通りを与えた5)。なお，実流 域を対象とした解析では河道下流端の境界条件には潮位 を与えるが，これに対応したものが「境界条件 I」であ り，予測解析のように水位八イドログラフが未知の場合 に適用したものが「境界条件II」である5.

解析の計算メッシュは，河道部・氾濫原部・堤防部は 
0.05(m), 開口部は0.01(m)を基準にした三角形非構造格 子で，その総数は検討Aでは24076，検討Bでは40422， 検討Cでは32380，検討Dでは24946である.

\section{4. 実験結果と解析結果の考察}

\section{(1) 検討 $A$}

図-7 9は，それぞれ河道下流端水位八イドログラフ $H$, 各開口部におけるFroude数の時系列 $F r$, 流出Q。あるいは 復流流量 $Q_{\mathrm{R}}$ ハイドログラフを示したものである.いず れも $Q_{\mathbb{N}}$ を河道下流端から越流を開始させた時刻を $t=0(\mathrm{~s})$ としている.

図-7 9に示した緑色の縦線は $Q_{\mathbb{N}}($ 図-3)を低下させた時 刻，黒丸は実験值，赤と青の実線はそれぞれ境界条件 I を用いた解析(以下「再現解析」という)と境界条件 II を 用いた解析(以下「予測解析」という)結果である.

まず実験結果について説明・考察する．図一7に示した Hについては, $t=0(\mathrm{~s})$ から急増し,$t \fallingdotseq 30(\mathrm{~s})$ 以降は緩やか に上昇寸る. その後, $t \doteqdot 300(\mathrm{~s})$ 加急減し, $t \doteqdot 340(\mathrm{~s})$ 以 降は緩やかに低下寸る．Hが以上のような傾向を示すの は, $t \fallingdotseq 30 \sim 300(\mathrm{~s})$ では両開口部からの流出によって河道 流量の増加が緩やかになり, $t \fallingdotseq 300(\mathrm{~s}) て ゙ は Q_{\mathbb{N}}$ が急減し, $t \fallingdotseq 340($ s)以降では両開口部から汇濫水が復流するために, 河道流量の減少が緩やかになるためである.

図-8に示した Frについては，Fr $F_{1} Ｆ r_{2}$ はそれぞれ $t \doteqdot 60(\mathrm{~s}), t \fallingdotseq 50(\mathrm{~s})$ でFr=1.0になり, $t \fallingdotseq 300$ (s)以降は常にFr $<1.0$ となる. このように，開口部1では $t \fallingdotseq 60(\mathrm{~s})$, 開口部

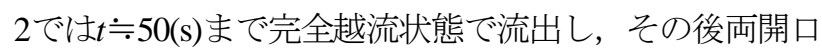

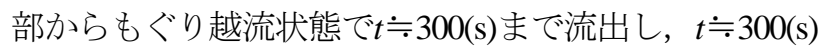
以降は復流する. 開口部1に比へて開口部2で完全越流か らもぐり越流状態一遷移する時刻が早くなるのは，汇濫 原2の水位が早期に上昇するためである. 寸なわち, 開 口部1からの流出によって開口部2より上流側の河道の流 速低下が生じ，それにより開口部2では開口部1に比べて 流出水の下流側への偏流が弱くなることで開口部下流断 面への衝突による水位の堰上げが小さくなるために, 開 口部2から流出しやすくなる. また $t \fallingdotseq 300(s)$ 以降で $F r_{1}$ と $\mathrm{Fr}_{2}$ の波形が異なっているのは，図-9からわかるように $Q_{\mathrm{R} 1}$ が $Q_{\mathrm{R} 2}$ に比べて小さく, 開口部1では開口部2に比べて 水位低下が遅れるためである.

図-9に示したQoについては， $Q_{01}, Q_{02}$ のいずれも $0(\mathrm{~s})$ から急増し,$t \fallingdotseq 40(\mathrm{~s})$ でピーク值を取った後に, $t \fallingdotseq$ 300(s)まで減少する， $Q_{01}$ と $Q_{02}$ のピーク值を取る時刻が ほぼ同じとなるのは，汇濫原1，2の面積が同じで，流出 直後で河道水位もほぼ同じ6であるためである。 また, $Q_{\mathrm{O} 2}$ のピーク值がQ $\mathrm{O}_{\mathrm{O}}$ より大きくなっているのは, Frで述 ベたように開口部2から流出しや寸いためである。 $Q_{\mathrm{R} 1}$, $Q_{\mathrm{R} 2}$ のいずれも $t \fallingdotseq 300(\mathrm{~s})$ から急増し, $t \fallingdotseq 310$ (s)でピーク值 を取った後に減少する. $t \doteqdot 310(\mathrm{~s})$ の $Q_{\mathrm{R} 1}$ のピーク值が $Q_{\mathrm{R} 2}$
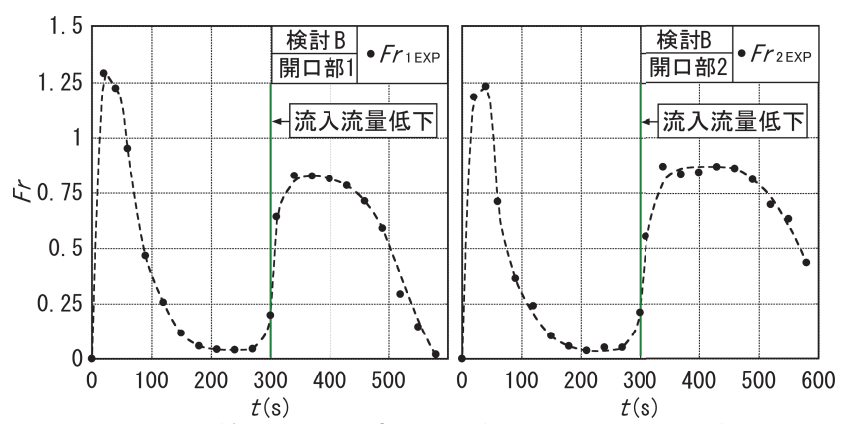

図-10 検討のの開口部の $F r$ (左 : $F r_{1}$, 右 : $F r_{2}$ )

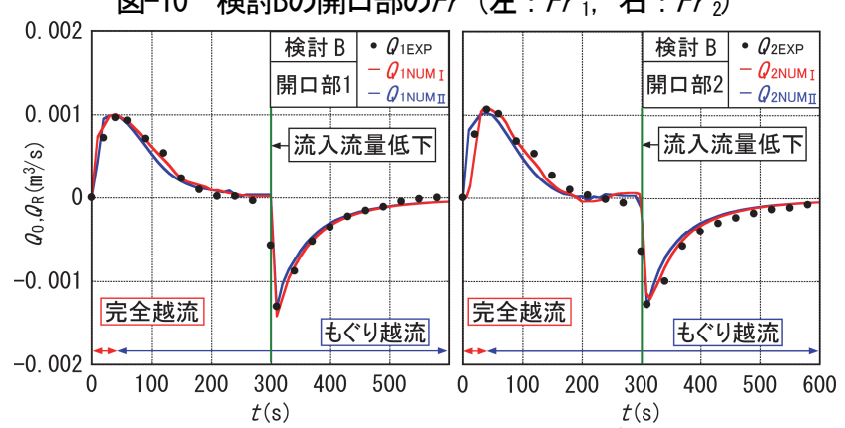

図-11 検討 $B$ 流出，復流流量ハイドログラフ $Q_{0}, Q_{R}$ (左: $Q_{1}$, 右: $Q_{2}$ )

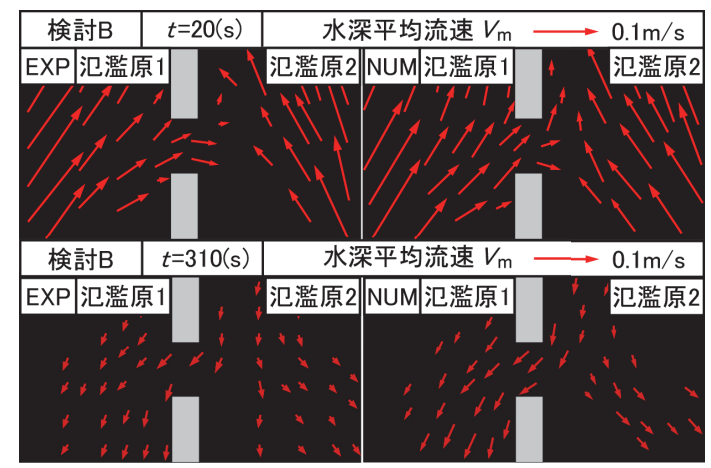

図-12 検討Bの通路近傍の流況

(上 : 流出時, 下 : 復流時) (左 : 実験結果, 右 : 解析結果)

より小さくなっているのは, 開口部1の上流側ではQ⿻上丨刃 流入し，下流側では開口部2から汇濫水が復流すること で, 開口部1付近で河道流量が増加するために, 開口部2 付近に比べて, 河道水位の低下が小さく, 開口部1から 復流し難くなることによる.

次に解析結果について考察する. 図-7，9からわかる ように, 解析結果は非定常性の強い不定流の河道下流端 水位, 各開口部からの流出および復流流量の実験結果を

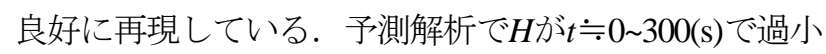

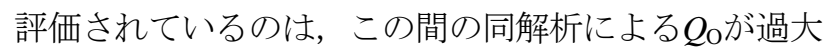
評価されているために, 河道流量が過小評価され, 河道 下流端のH-q関係に影響を及ぼすためである， $Q_{\mathrm{O}} ， Q_{\mathrm{R}}$ の ピーク值が過大あるいは過小評価されているのは, PTV 解析による $v_{\mathrm{P}}$ の測定誤差による，ただし， $Q_{\mathrm{O}}, Q_{\mathrm{R}}$ のい ずれも $10 \%$ 程度の誤差の範囲に収まっており，検討 B Dについても誤差の程度は同様であった. なお，検討 B D の下流端水位八イドログラフ $H$ の実験と解析結果の 比較は，検討Aとほぼ同様であったので，紙面の都合か ら割愛する。 


\section{(2) 検討 $B$}

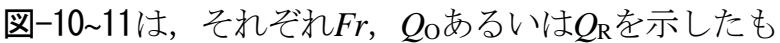
のである. 図-12は実験と予測解析から得られた氾濫原 部の通路近傍の流況を示したもので，図中の赤のベクト ルは $t=20,310(\mathrm{~s})$ における各地点の水深 $h$ 表面流速 $V_{\mathrm{P}}$ よ り算定された水深平均流速 $V_{\mathrm{m}}$ である.

以下，検討Aと比較して考察する. 実験結果について は, $F r_{1}$ が検討Aに比べて $t \fallingdotseq 340(\mathrm{~s})$ 以降で早期に減少して いるのは, $t \fallingdotseq 310(\mathrm{~s})$ から通路を介して, 汇濫原2の汇濫 水が汇濫原 1 一流入し, $t \fallingdotseq 340(\mathrm{~s})$ 以降の汇濫原 1 の水位低 下が緩やかになるためである. $t \fallingdotseq 310(\mathrm{~s}) の Q_{\mathrm{R} 1}$ と $Q_{\mathrm{R} 2}$ の ピーク值の差が小さくなっているのは，図-12からわか るように, 復流開始時は汇濫原2から通路を介して氾濫

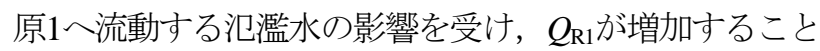
による.

以上のように，汇濫原を分断する道路等に通路がある 場合は，両開口部からもぐり越流状態で流出する間は通 路を通過する汇濫水の流量も小さくなるため, $Q_{\mathrm{O}}, Q_{\mathrm{R}}$ の波形は検討A と同様となるが，両開口部から復流寸る 間は通路を通過する汇濫水の影響を受けるため，その波 形は検討Aと異なってくる.

解析結果については，図-11 12からわかるように，実 験結果を良好に再現しているが，Qo， $Q_{\mathrm{R}}$ のピーク值が 若干過大あるいは過小評価されている。これは，検討A と同様の理由に加え, 通路部の縮流により, 実験と解析 の氾濫原の流況に若干の違いが生じるためである.

\section{(3) 検討 C}

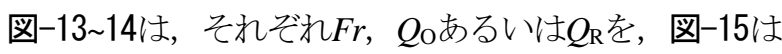
低地盤高区間近傍のt=140，310(s)の流況を示したもので ある. 実験結果については，検討A，Bに比べて $F r_{1} ， F r_{2}$ がそれぞれ $t \fallingdotseq 40(\mathrm{~s}), t \fallingdotseq 20(\mathrm{~s}) て ゙ F r=1.0$ になり，両開口部 で完全越流からもぐり越流状態一遷移する時刻が早く

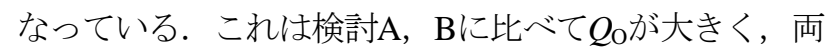
氾濫原の水位が早期に上昇するためである. $t \fallingdotseq 340(s)$ 以 降のFr $1, t \fallingdotseq 310(\mathrm{~s})$ 以降の $F r_{2}$ が早期に減少しているのは, $t \fallingdotseq 310(\mathrm{~s})$ 以降は汇濫原2の汇濫水が低地盤高区間から氾 濫原1へ越流することで $Q_{\mathrm{R} 1}$ が増加し，河道水位が上昇す るために，両汇濫原の水位低下が緩やかになることによ る. Qoが $t \fallingdotseq 150 \sim 300(\mathrm{~s})$ で大きくなっているのは, $t \fallingdotseq$ 140(s)以降は汇濫原1の氾濫水が低地盤高区間から氾濫原 2へ越流することにより開口部1から流出し続けるためで ある. $t \fallingdotseq 310(\mathrm{~s}) の Q_{\mathrm{R} 1}$ と $Q_{\mathrm{R} 2}$ のピーク值の差は検討Aに比 べて小さく, 検討Bに比べて大きくなっている. $t \fallingdotseq$ 210 300(s) と $\fallingdotseq \fallingdotseq 310(\mathrm{~s})$ の $Q_{\mathrm{R} 2}$ の違いはQ $Q_{01}$ と同様である. 検討 $\mathrm{B} の Q_{\mathrm{R} 1}$ と $Q_{\mathrm{R} 2}$ との違いが大きくなっているのは, 図12，15に示した流速ベクトルからわかるように，復流時 により多くの汇濫水が汇濫原 2 から1へ越流・流入寸るた めである.

以上のように，氾濫原を分断寸る道路等の一部区間が

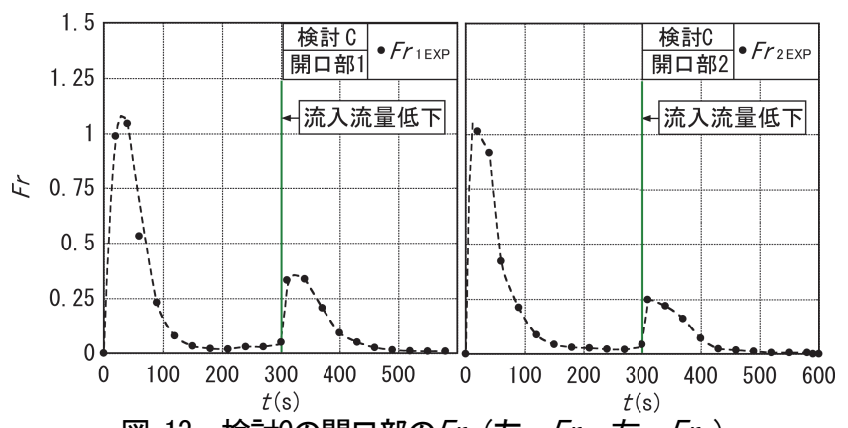

図-13 検討Cの開口部の $F r$ (左 : $F r_{1}$, 右 : $F r_{2}$ )

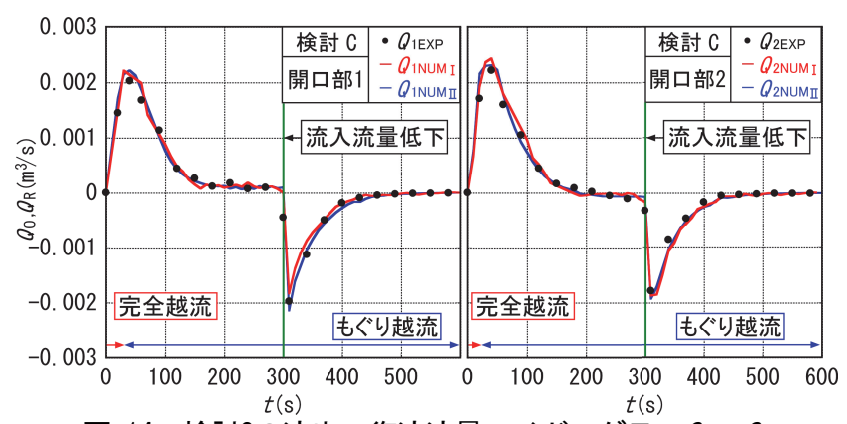

図-14 検討Cの流出，復流流量ハイドログラフ $Q_{0}, Q_{R}$ (左: $Q_{1}$, 右: $Q_{2}$ )

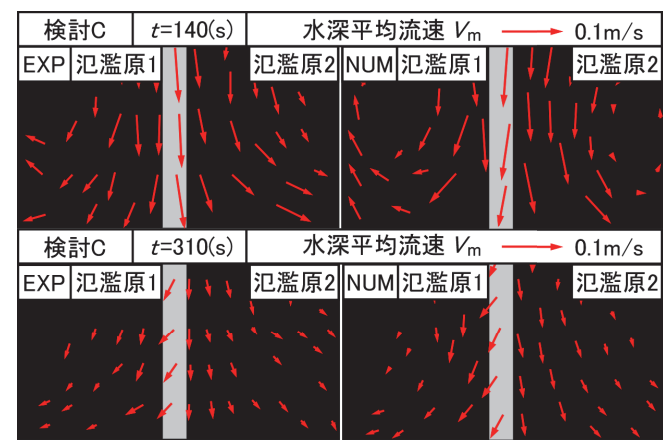

図-15 検討Cの低地盤高区間近傍の流況

(上 : 流出時, 下 : 復流時) (左 : 実験結果, 右 : 解析結果)

低くなっている場合は，両開口部から完全越流状態で流

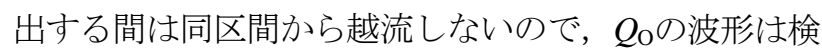
討A と同様になるが，両開口部からもぐり越流状態で流 出あるいは復流する間は, 越流の影響を受け, $Q_{\mathrm{O}} / Q_{\mathrm{R}}$ の 波形は検討A，Bと異なってくる.

解析結果については，図-14 15からわかるように，実 験結果を良好に再現しているが，Qo， $Q_{\mathrm{R}}$ のピーク值が 過大あるいは過小評価されている。 これは検討Aと同様 の理由に加え，低地盤高区間の越流水深の低下に伴って， 流況に若干の違いが生じるためである.

\section{(4) 検討 $D$}

図-16 17はそれぞれFr，Q⿻ある冖いは $Q_{R}$ 示したもの

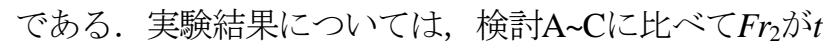
○20 60(s)で急減しているのは，図-5，6で示したように, 流出水は汇濫原下流側に偏って開口部から流出するため に, 汇濫原上流側の水位が低下寸る一方で, 汇濫原下流 側の水位が早期に上昇するためである. $t \doteqdot 40(\mathrm{~s})$ の $Q_{01}$ と $\mathrm{Q}_{\mathrm{O} 2}$ の差が検討 $\mathrm{A} \sim \mathrm{C} に$ 比べて小さくなっているのは, Fr 
で述べたように，氾濫原下流側の水位が上昇するためで

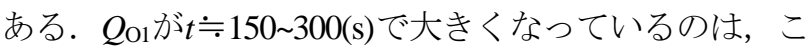
の間の汇濫水が汇濫原上流側から下流側への流動が生じ, Q o1 $_{1}$ 流出し続けるためである. $t \fallingdotseq 180 ~ 300(\mathrm{~s}) て ゙ Q_{\mathrm{R} 2}$ が大 きくなっており, $t \doteqdot 310(\mathrm{~s}) の Q_{\mathrm{R} 1}$ と $Q_{\mathrm{R} 2}$ の差は小さくなっ ているが， $t \fallingdotseq 180 \sim 300(\mathrm{~s}) の Q_{\mathrm{R} 2}$ の違いは，Q01 $Q_{01}$ 同様であ る. $t \fallingdotseq 310(\mathrm{~s}) の Q_{\mathrm{R} 1}\left\llcorner Q_{\mathrm{R} 2}\right.$ の差の違いは, $t \fallingdotseq 300(\mathrm{~s})$ 以降で は氾濫原下流側の氾濫水が汇濫原上流側に流入するため

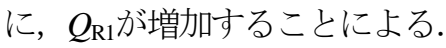

以上のように，汇濫原が分断されていない場合は，越 流状態に関わらず，両開口部から流出あるいは復流する 間は，両開口部からの流出水等が汇濫原上流側から下流 側への氾濫水の流動の影響を受けるため, $Q_{0} / Q_{\mathrm{R}}$ の波形 が検討A C と異なってくる.

解析結果については，図-17からわかるように，実験 結果を良好に再現しているが，Qo， $Q_{\mathrm{R}}$ のピーク值が過 大あるいは過小評価されている。これは，検討Aと同様 の理由に加え，両開口部からの流出水が汇濫原を流動す る汇濫水の影響を受けるためである.

\section{5. まとめ}

検討A Dを俯瞰すれば，本実験条件下では，流出ある いは復流流量について，下記(1)，(2)のような傾向が見ら れた。 また，本解析法が河道上下流端の境界条件を所与 の条件として，検討 $\mathrm{A}$ Dのような汇濫原特性の違いを考 慮したうえで，河道に沿った2箇所の決壊口から非定常 常状態で流出あるいは復流する流量を $10 \%$ 以内の誤差で 良好に再現可能であることを実証した.

(1)各開口部からもぐり越流状態で流出あるいは復流が 生じる状況では, 検討 $\mathrm{A}, \mathrm{B}, \mathrm{C}, \mathrm{D} の$ 順に $\mathrm{Q}_{\mathrm{O} 1}, \mathrm{Q}_{\mathrm{R} 2}$ が増 加し, 両開口部から復流開始以降は各開口部からの復流 のピーク值の差が小さくなる. 汇濫原が道路等で完全に 分断された場合は, 汇濫原湛水時には開口部から流出あ るいは復流は当然生じないが，道路等の通路や低地盤高 区間等を介して汇濫原間で汇濫水の流動が生じる場合は, 汇濫原湛水時でももぐり越流状態で上流側開口部から流 出し，下流側開口部から復流が生じる。 また，汇濫原間 で汇濫水の流動が生じる場合には，検討B，C，Dの順に， 各開口部での流出あるいは復流流量が大きくなる.

(2)各開口部から完全越流状態で流出寸る状況では，検 討A Cの各開口部からの流出流のピーク值の差はほぼ同

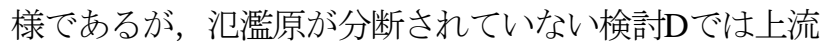
側開口部からの流出水が早期に下流側開口部に影響を及 ぼし，流出流のピーク值の差が小さくなる.

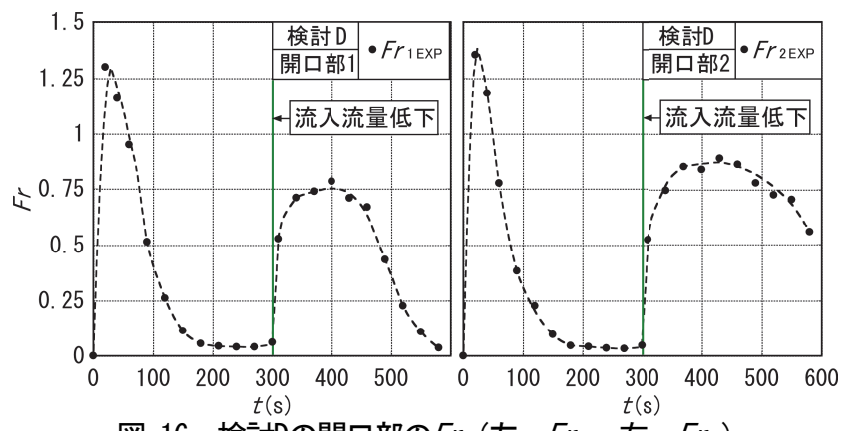

図-16 検討Dの開口部の $F r$ (左 : $F r_{1}$, 右 : $F r_{2}$ )

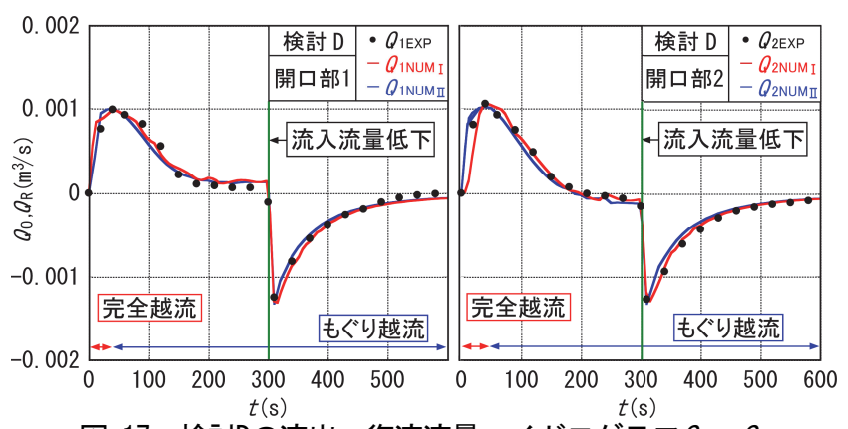

図-17 検討Dの流出，復流流量ハイドログラフ $Q_{0}, Q_{R}$ (左: $Q_{1}$, 右: $Q_{2}$ )

\section{参考文献}

1) 秋山壽一郎 : 減災型治水に求められる河川技術の展望と課 題, 第50回水工学に関する夏期研修会 Aコース, 2014.

2）例えば, 秋山壽一郎, 重枝末玲, 草野浩之: 都市域浸水・減 災対策検討シミュレータによる飯塚市街地の浸水被害評価, 土木学会論文集B1(水工学), vol.68, No.4, I_1036-I_1068, 2012.

3) 秋山壽一郎, 重枝末玲, 野村心平 : 数值シミュレーション に基づく短時間豪雨に対する遠賀川流域の洪水と飯塚市街 地の浸水特性の検討, 土木学会論文集B1(水工学), vol.69, No.4, I_1579-I_1584, 2013.

4) 秋山壽一郎，重枝末玲，小園裕司，草野浩之 : 治水システ ムを考慮した飯塚市街地の都市域汇濫解析と被害軽減効果 の検討, 水工学論文集, 第55巻, pp.943-948, 2011.

5) 秋山壽一郎, 重枝末玲, 田島瑞規: 数值解析を用いた遊水 地の洪水調節効果の評価 - 牟田辺遊水地を対象として - , 土木学会論文集B1(水工学), vol.70, No.4, I_847-I_852, 2014.

6) 秋山壽一郎, 重枝末玲, 松本創次郎, 中上竜吾 : 複数䇢所 で汇濫・復流する洪水汇濫流の数值解析とその検証，土木 学会論文集B1(水工学), vol.71, No.4, I_1477-I_1482, 2015.

7) 秋山壽一郎, 重枝末玲, 大庭康平: 直線河道におけ破堤 汇濫流量式の横越流特性と流量式の改善, 水工学論文集, 第55巻, pp.901-906, 2011.

8) 秋山壽一郎, 重枝未玲, 大庭康平, 山尾匡人, 門田竜祐 : 直線・蛇行河道における破堤汇濫流の特性とその予測，土 木学会論文集B1(水工学), vol.68, No.4, I_1021-I_1026, 2012.

(2015. 9. 30受付) 